\title{
SENSE OF COHERENCE AND TINNITUS ANNOYANCE IN ADULTS
}

\section{Contributions: A Study design/planning B Data collection/entry C Data analysis/statistics D Data interpretation E Preparation of manuscript F Literature analysis/search $\mathrm{G}$ Funds collection}

\section{Justyna Paluchowska ${ }^{1, A-B, D-F}$, Małgorzata Fludra ${ }^{2, A-F}$, Joanna Kobosko ${ }^{3, C-E}$, Elżbieta Gos ${ }^{3, C-D}$, Henryk Skarzynski ${ }^{4, E}$}

\author{
${ }^{1}$ Rehabilitation Clinic, Institute of Physiology and Pathology of Hearing, Poland \\ ${ }^{2}$ Tinnitus Clinic, Institute of Physiology and Pathology of Hearing, Poland \\ ${ }^{3}$ Teleaudiology and Screening Department, Institute of Physiology and \\ Pathology of Hearing, Poland \\ ${ }^{4}$ Oto-Rhino-Laryngology Surgery Clinic, Institute of Physiology and \\ Pathology of Hearing, Poland
}

Corresponding author: Justyna Paluchowska; Rehabilitation Clinic, Institute of Physiology and Pathology of Hearing, Mokra 17, Kajetany 05-830, Nadarzyn, Poland; email: j.paluchowska@ifps.org.pl

\section{Abstract}

Introduction: Tinnitus is usually a chronic (ongoing) condition which in many cases significantly impairs the affected person's quality of life. Their habituation to tinnitus depends on the patient's personality resources. The aim of this research was to determine if a particular psychological meta-resource, in this case a sense of coherence, is related to the perceived annoyance of tinnitus.

Material and methods: The study included 176 people (123 females, 53 males) aged $31-80(\mathrm{M}=59.1)$ diagnosed with tinnitus. To measure the sense of coherence, we used the Sense of Coherence Questionnaire (SOC 29), and to evaluate the tinnitus annoyance, we used the Tinnitus Handicap Inventory (THI). The subjects also filled in a survey to capture sociodemographic data and their medical history.

Results: The sense of coherence (in total and in particular aspects) turned out to be significantly correlated with tinnitus annoyance (in total and in particular aspects). The overall level of coherence turned out to be an essential predictor for the overall level of tinnitus annoyance. The degree of manageability was a particularly important component of the sense of coherence which affected tinnitus annoyance.

Conclusions: In people with a strong sense of coherence, especially with a strong manageability component, there is a lower level of tinnitus annoyance. Psychological interventions - counselling, psychoeducation, psychotherapy - support the development of a sense of coherence and can reduce tinnitus annoyance.

Key words: sense of coherence $\bullet$ tinnitus • personal resources

\section{POCZUCIE KOHERENCJI A ODCZUWANA DOKUCZLIWOŚĆ SZUMÓW USZNYCH U OSÓB DOROSŁYCH}

\section{Streszczenie}

Cel: Szumy uszne to zwykle przewlekła dolegliwość, w wielu przypadkach znacząco pogarszająca jakość życia doświadczających jej osób. Łatwość, z jaką osoby te dostosowują się do szumów usznych, zależy między innymi od posiadanych przez nie zasobów osobowościowych. Celem badania było określenie, czy metazasób, jakim jest poczucie koherencji, pozostaje w związku z odczuwaną dokuczliwością szumów usznych.

Materiał i metoda: Uczestnikami badania było 176 osób (123 kobiet, 53 mężczyzn) w wieku 31-80 (M = 59,1) ze zdiagnozowanymi szumami usznymi. Do pomiaru poczucia koherencji użyto Kwestionariusza Orientacji Życiowej (SOC 29), natomiast do oceny dokuczliwości szumów usznych kwestionariusza Tinnitus Handicap Inventory (THI). Badani wypełniali również ankietę zawierającą pytania o dane socjodemograficzne i historię dolegliwości.

Wyniki: Poczucie koherencji (ogółem i w poszczególnych wymiarach) okazało się istotnie skorelowane z uciążliwością szumów usznych (ogółem i w poszczególnych wymiarach). Ogólny poziom koherencji okazał się istotnym predyktorem dla ogólnego wyniku uciążliwości szumów usznych. Poczucie zaradności okazało się szczególnie istotnym komponentem poczucia koherencji wpływającym na dokuczliwość szumów usznych.

Wnioski:

- U osób o wysokim poziomie poczucia koherencji, a zwłaszcza jego komponentu, jakim jest poczucie zaradności, można spodziewać się mniejszej dokuczliwości szumów usznych.

- Interwencje psychologiczne w różnej formie (poradnictwo, psychoedukacja, psychoterapia) wpływające na rozwój poczucia koherencji mogą zmniejszać dokuczliwość szumów usznych.

- Należy kontynuować badania mające na celu poszukiwanie innych zasobów osobistych wpływających na odczuwalną dokuczliwość szumów usznych.

Słowa kluczowe: poczucie koherencji • szumy uszne • zasoby osobiste 


\section{Introduction}

In health psychology, when looking for factors that help a person cope with illness and recovery, a number of scientists have applied the salutogenic approach introduced by A. Antonovsky. Contrary to the pathogenic approach, which studies causes of disease, it focuses on the functioning of a human being as a biopsychosocial entity [1].

The salutogenic approach defines health as a dynamic process of maintaining a relative balance between the environmental requirements and the resources available in confronting stress. According to Antonovsky, every human is on a continuum between perfect health and total illness. External environmental and internal factors, if assessed by an individual as being negative, develop tension. This may disturb the body's balance, cause stress, and overburden it, leading to a breakdown of the immune system and a shift along the continuum in the direction of total illness [2]. Human resources are crucial for maintaining balance and active coping with tension. Since stressors are ubiquitous and cannot be avoided, it is essential to identify an individual's strengthening resources which assist in maintaining balance, and thus health. Tinnitus can be one factor that disrupts the balance. Tinnitus means awareness of a sound that has no actual external source, in the ears or in the head [3]. Subjective tinnitus occurs in most cases and is heard only by the person experiencing it. It is caused by abnormal neuronal activity that is interpreted as sound.

The degree of tinnitus annoyance can vary despite similar sound volume and frequencies [4]. Researchers therefore look for additional factors other than audiological parameters that may affect the perception of tinnitus. This research includes, among others, human personality traits. People who describe tinnitus as not very annoying are more open to new experiences (one of the personality factors according to the Big Five model) than those who assess tinnitus as medium or very annoying [5]. Other studies indicate a higher level of neuroticism and a lower level of extraversion in people with tinnitus as related to its annoyance [6]. However, studies by Andersson and Vretblad have shown that people who experience annoying tinnitus more often show depressive or anxiety tendencies $[7,8]$.

The pathophysiology of tinnitus is studied in the context of somatosensory function and brain processes, including limbic system activity. Scientists have identified 14 subregions associated with tinnitus, among them being the auditory cortex, prefrontal lobe, dorsal cochlear nucleus, hippocampus, amygdala, and thalamus [9]. The occurrence of tinnitus in a patient significantly worsens their quality of life. Research indicates that as well as cognitive functions such as attention, information processing, and memory $[10,11]$, tinnitus also negatively affects emotional functions - and can cause or intensify anxiety and depressive disorders [12-14]. Most people suffering tinnitus also have a sleep disorder $[15,16]$. It is estimated that tinnitus affects $10-19 \%$ of the adult population, and its incidence increases with age [17]. The annoyance and chronic nature of this ailment prompted us to look for resources that might help people with tinnitus adapt to the situation and regain their lost psychological balance.
In the salutogenic approach, the sense of coherence (SOC) - meaning the person's general attitude that determines the way they perceive and understand the world - is considered a 'meta-resource' that has the overall function of managing the use of an individual's remaining resources. The sense of coherence is a personality variable that is shaped by the process of learning and socialization [18]. Studies have shown that a higher sense of coherence is a good predictor of how a person handles situations and of a better quality of life in cases of cancer [19], Parkinson's disease [20], and congenital heart disease [21-23].

There are three components to the sense of coherence: comprehensibility, manageability, and meaningfulness. Comprehensibility means that stimuli reaching a person are perceived by them as predictable, explainable, and understandable. Manageability refers to how a person assesses their own resources - both internal (e.g. self-efficacy, locus of control, cognitive competence, coping strategies) and the ones provided by the environment (e.g. family, beliefs, authorities), which are necessary to cope with encountered difficulties. People with a strong manageability component will look for solutions, as they are convinced that by using their resources they can affect their situation. Meaningfulness is connected with life's purpose and meaning, with all encountered difficulties perceived as challenges worthy of commitment and effort.

The construct of a sense of coherence can be described as a human cognitive tendency to evaluate stressful situations. Under this assumption, people with a strong sense of coherence in a stressful condition (such as chronic disease or ailment) perceive the world more realistically, and they mobilize themselves and activate their resources. It leads to an efficacy in handling problems and reduces tension, which in turn helps the person retain their balance and lets them return to normal more quickly.

The present authors found only one report on the relationship between tinnitus annoyance and the sense of coherence in the available literature. This report showed a significantly negative correlation between these variables [24].

The aim of the present study was to determine if the meta-resource - the sense of coherence - affected the perceived annoyance of tinnitus. It seemed to us that people with a strong sense of coherence, who understand their situation well and have a good sense of self-agency, would tend to deal better with their inner tension and would subjectively assess their tinnitus as less annoying.

\section{Material}

The research included 176 patients (123 females, 53 males) aged 31 to 80 years $(M=59.1 ; S D=9.6)$ attending the Institute of Physiology and Pathology of Hearing suffering from tinnitus. The duration of tinnitus was 6 months to 30 years $(M=8.34, S D=6.12$ years $)$ which means that all patients included in the research were experiencing chronic tinnitus (lasting over 6 months) [3]. Bilateral tinnitus, perceived in both ears and/or the head, was reported by 118 patients $(67 \%)$, while single-sided tinnitus was reported by $58(33 \%)$. Pure tone audiometry (arithmetic 
mean of hearing thresholds for the following frequencies: $0.5,1,2,4 \mathrm{kHz}$ ) confirmed normal hearing in $45.5 \%$ of the examined patients. The remaining $54.5 \%$ of patients were found to have a single or bilateral hearing loss.

The subjects completed a questionnaire by themselves during audiological visits or hospitalizations. The study was approved by the Bioethics Committee of the Institute of Physiology and Pathology of Hearing (No. KB/10/2016).

\section{Methods}

All participants of the research were asked to fill in the following forms.

1. Antonovsky's Sense of Coherence Scale (SOC 29) [2] in a Polish adaptation by Koniarek et al. [20]. The test consists of 29 items, each of which is scored on a 7 -point Likert scale. The maximum score is 203 points. The result can be interpreted in a general context, but it also allows one to conduct measurements of three components of the sense of coherence. (a) Comprehensibility (11 items, maximum 77 points): e.g., "In the past ten years your life has been..." (answer from 1 - full of changes without you knowing what will happen next to 7 - completely consistent and clear). (b) Manageability (10 items, maximum 70 points): e.g. "Life is..." (answer from 1 - full of interest to 7 - completely routine). (c) Meaningfulness (8 items, maximum 56 points): e.g., "You anticipate that your personal life in future will be..." (answer from 1 - totally without meaning or purpose to 7 - full of meaning or purpose). The higher the score, calculated according to the instructions, the higher the sense of coherence and its components.

2. Tinnitus Handicap Inventory (THI) applied to determine the impact of tinnitus on the everyday life of the patient. The questionnaire by Newman et al. [26], in the Polish adaptation by Skarżyński et al. [27], consists of 25 items and has 3 subscales: (a) Functional (evaluates the limitations caused by tinnitus in social, cognitive, and physical functioning), e.g., "Does your tinnitus make you feel confused?". (b) Emotional (evaluates emotions and states accompanying tinnitus), e.g., "Does your tinnitus make you upset?". (c) Catastrophic reactions (evaluates catastrophic responses to tinnitus), e.g., "Do you feel that you can no longer cope with your tinnitus?". The respondent chooses one of three answers: Yes (4 points), Sometimes ( 2 points), No (0 points). The maximum score is 100 points. The higher the score, the higher the grade on the 5-point tinnitus severity scale.

3. A survey on sociodemographic data (gender, age, marital status, education, professional activity), history of tinnitus (duration, location), and occurrence of additional diseases (diabetes, depressive epilepsy, obesity, cancer, cardiovascular, respiratory, and other).

To study the relationship between the sense of coherence and tinnitus annoyance, we performed correlations and regressions. The adopted statistical significance was $\alpha=0.05$. IBM SPSS Statistics (v. 24) was used for statistical analyses.

\section{Results}

\section{The level of the sense of coherence}

Table 1 presents detailed results obtained in the examined group with the SOC 29 questionnaire. In the studied group of people with tinnitus, the average level of the sense of coherence was $133.9(\mathrm{SD}=26.9)$.

Table 1. Descriptive statistics for sense of coherence and its components

\begin{tabular}{lcccc}
\hline & Min & Max & M & SD \\
\hline Comprehensibility & 11 & 77 & 45.01 & 11.73 \\
\hline Manageability & 15 & 70 & 47.03 & 10.32 \\
\hline Meaningfulness & 20 & 56 & 41.85 & 7.77 \\
\hline $\begin{array}{l}\text { Sense of coherence - } \\
\text { general }\end{array}$ & 56 & 203 & 133.89 & 26.92 \\
\hline
\end{tabular}

M, mean; SD, standard deviation

A weak sense of coherence in total (stens 1-4) was assessed in 16 persons (9\%), an average sense of coherence (stens 5-6) was found in 115 people (65.3\%), and a strong sense of coherence (stens 7-10) was found in 45 people $(25.6 \%)$

We next examined the impact of sociodemographic variables on the level of the sense of coherence. The variables were gender, age, marital status, education, professional activity, and health-related variables, the latter being duration of tinnitus, hearing condition (divided into the absence/presence of hearing loss), and the presence or absence of other diseases. The results of a $t$-test for independent samples showed that men had a significantly higher total score for the sense of coherence in comparison to women (females: $\mathrm{M}=130.7$, $\mathrm{SD}=27.1$; males $\mathrm{M}=141.3, \mathrm{SD}=25.3 ; t=2.42 ; p<0.05)$ and had significantly higher scores for two components of this resource: comprehensibility (females: $\mathrm{M}=43.6, \mathrm{SD}=11.7$; males: $\mathrm{M}=48.3, \mathrm{SD}=11.1 ; t=2.49 ; p<0.05)$ and manageability (females: $\mathrm{M}=45.9, \mathrm{SD}=10.6$; males: $\mathrm{M}=49.6$, $\mathrm{SD}=9.2 ; t=2.23 ; p<0.05)$, while meaningfulness was on a similar level (females: $\mathrm{M}=41.2, \mathrm{SD}=7.6$; males: $\mathrm{M}=43.3, \mathrm{SD}=8.1 ; t(174)=1.66 ; p>0.05)$.

A $t$-test for independent samples showed that in people who do not have additional diseases, the sense of coherence (in total and in individual dimensions) was significantly stronger than in people with comorbidities (Table 2).

There were no relationships (checked with $t$-tests or Pearson correlation coefficients) between the sense of coherence and age, marital status, education, professional activity, and duration of tinnitus. There were also no differences in the sense of coherence between people with normal hearing and people with hearing loss.

\section{Level of tinnitus annoyance}

Tinnitus annoyance as assessed with the THI questionnaire fluctuated from 2 to 98 points, with a mean of 
$44.8(S D=21.1)$. This means that, on average, tinnitus had a moderate impact (3rd degree of annoyance) on the lives of the examined patients.

\section{The relationship between the sense of coherence and the annoyance of tinnitus}

The relationship between the sense of coherence and tinnitus annoyance was investigated using correlation analysis. The Pearson $r$-correlation coefficients between the variables were statistically significant $(p<0.01)$ and are presented in Table 3.

The sense of coherence (in total and in each aspect) turned out to be significantly correlated with tinnitus annoyance (in total and in respective aspects). The higher the level of the sense of coherence, the lower the tinnitus annoyance in functional, emotional, and catastrophic dimensions, and the lower the overall annoyance.

To find out which dimension of the sense of coherence was the most important and for which aspects of tinnitus annoyance (measured by the THI questionnaire), multivariate regression analysis was performed separately for each aspect of tinnitus annoyance (multicollinearity was checked and variance inflation factor was at an acceptable level -between 2.1 and 3.3). The following dimensions of tinnitus annoyance (functional, emotional, catastrophic, general) were adopted as the dependent variable. Three aspects of the sense of coherence (the sense of comprehensibility, the sense of manageability, the sense of meaningfulness) were taken into account as predictors. The analysis showed that for all dimensions of tinnitus annoyance, the sense of manageability turned out to be a significant predictor (Table 4).

Figure 1 and Figure 2 show the relationship between tinnitus annoyance and sense of coherence, and between tinnitus annoyance and manageability.

Summing up, the values of the regression coefficients and their significance leads to the conclusion that a sense of coherence is essential for tinnitus to be experienced as annoying. In a person with a substantially high level of the coherence variable, lower tinnitus annoyance can be expected. The sense of manageability turned out to be a particularly important component of the sense of coherence influencing the annoyance of tinnitus.

\section{Discussion}

Tinnitus has been the subject of numerous studies, most of which have focused on difficulties that accompany the ailment. Positive psychology has set a new direction in research on how people adapt to chronic disease or illness. It focuses on the personal resources which individuals can call on to maintain health and, in the event of illness or ailment, to deal with it better and faster. Our research, therefore, is part of this trend. It is a continuation of studies into important personal resources that are involved when assessing the annoyance of tinnitus [28].

In this study, the average level of the sense of coherence in the group of people with tinnitus was 133.9, which is a result similar to Antonovsky's normative research [2] and some Polish research [29]. Thus, the studied population of adults with tinnitus does not differ significantly from the above in terms of the intensity of this personality trait.

In our subjects with tinnitus, the total results on the SOC 29 scale of the sense of coherence, and the three sub-scales, indicate it has a higher level in men than in women, which is consistent with the review of studies on SOC conducted by Eriksson et al. [30]. Men also had higher scores than women in two components of the sense of coherence - the sense of comprehensibility and the sense of manageability. Thus men perceive the world as more explainable and predictable, and feel they have sufficient competence and/or capacity to meet the demands of the situations they experience.

A significantly better result, both in total and individual aspects of the sense of coherence, was recorded in the group who did not declare any additional diseases, compared to those who did. This is consistent with the salutogenic model of health, where the sense of coherence plays the role of a moderator with the declared health assessment. In stressful situations, such as disease or illness, the perception of better health coexists with a higher level of coherence. This relationship is also confirmed by a review of research on SOC by Eriksson and Lindstrom [31].

It can be assumed that the sense of coherence, even though it is by definition a personality trait, is subject to specific changes (lowering) related to the presence of comorbidities in people with tinnitus, and this requires further research.

Our results confirm the expected relationship between the sense of coherence and perceived tinnitus annoyance, which is consistent with the results obtained by Seydel et al. [24]. It means that people with a higher sense of coherence may cope better with tinnitus. Manageability turned out to be the main component of the sense of coherence affecting the well-being of people with tinnitus. Other elements of the sense of coherence are no doubt also important for the assessment of perceived annoyance of tinnitus, but their predictive properties were not shown in this study. It therefore seems that people with a high sense of manageability are convinced they can cope with their situation. More often they treat the occurrence of a chronic ailment such as tinnitus as a challenge. They thus experience less negative emotions, which in turn affects the assessment of the severity of tinnitus [32].

The results of this research could have an impact on clinical work with people experiencing tinnitus. Antonovsky, in the theory of the salutogenic approach, noted that the sense of coherence keeps developing until about 30 years of age. Nevertheless, studies indicate that SOC may also increase later, after psychotherapeutic interventions, which has been observed after treatment of people addicted to alcohol [33] and marijuana [34], as well as 6 months after the end of a 10-week treatment of people with neurotic disorders [35]. It is also worth paying attention to the research by Weissbecker et al. on the effectiveness of MindfulnessBased Stress Reduction (MBSR) therapy used to increase the sense of coherence [36]. 
Table 2. Sense of coherence and the presence of other diseases

\begin{tabular}{|c|c|c|c|c|c|c|}
\hline & \multicolumn{2}{|c|}{$\begin{array}{l}\text { Lack of other diseases } \\
\qquad(n=41)\end{array}$} & \multicolumn{2}{|c|}{$\begin{array}{l}\text { Presence of other } \\
\text { diseases }(n=135)\end{array}$} & \multirow[t]{2}{*}{$t(174)$} & \multirow{2}{*}{$p$} \\
\hline & M & SD & M & SD & & \\
\hline Comprehensibility & 49.29 & 10.41 & 43.71 & 11.84 & 2.72 & 0.007 \\
\hline Manageability & 50.88 & 9.52 & 45.87 & 10.30 & 2.78 & 0.006 \\
\hline Meaningfulness & 44.63 & 7.94 & 41.00 & 7.54 & 2.67 & 0.008 \\
\hline Sense of coherence- general & 144.80 & 24.78 & 130.58 & 26.75 & 3.03 & 0.003 \\
\hline
\end{tabular}

$t$, value of the test statistic; $p$, statistical significance

Table 3. Correlations between the sense of coherence and tinnitus annoyance (THI)

\begin{tabular}{lcccc}
\hline & Functional Scale & Emotional Scale & $\begin{array}{c}\text { Catastrophic } \\
\text { Reactions Scale }\end{array}$ & $\begin{array}{c}\text { THI } \\
\text { general score }\end{array}$ \\
\hline Comprehensibility & $-0.38^{* *}$ & $-0.32^{* *}$ & $-0.23^{* *}$ & $-0.36^{* *}$ \\
\hline Manageability & $-0.43^{* *}$ & $-0.38^{* *}$ & $-0.30^{* *}$ & $-0.43^{* *}$ \\
\hline Meaningfulness & $-0.32^{* *}$ & $-0.30^{* *}$ & $-0.20^{* *}$ & $-0.32^{* *}$ \\
\hline Sense of coherence- general & $-0.42^{* *}$ & $-0.37^{* *}$ & $-0.27^{* *}$ & $-0.41^{* *}$ \\
\hline$* * 0<0.01$ & & &
\end{tabular}

${ }^{* *} p<0.01$

Table 4. Results of regression analysis for the annoyance of tinnitus in all dimensions due to a sense of coherence

\begin{tabular}{|c|c|c|c|c|c|c|c|c|}
\hline & \multicolumn{2}{|c|}{$\begin{array}{l}\text { THI Functional Scale } \\
R^{2} \text { adj }=0.172 ; \\
F=13.11^{* *}\end{array}$} & \multicolumn{2}{|c|}{$\begin{array}{l}\text { THI Emotional Scale } \\
R^{2} \text { adj }=0.130 ; \\
F=9.71^{* *}\end{array}$} & \multicolumn{2}{|c|}{$\begin{array}{c}\text { THI Catastrophic } \\
\text { Reactions Scale } \\
R_{\text {adj }}^{2}=0.073 ; \\
F=5.61^{* *}\end{array}$} & \multicolumn{2}{|c|}{$\begin{array}{c}\text { THI } \\
\text { Total } \\
R^{2} \text { adj }=0.169 ; \\
F=12.85^{* *}\end{array}$} \\
\hline & $\beta$ & $p$ & $\beta$ & $p$ & $\beta$ & $p$ & $\beta$ & $p$ \\
\hline Comprehensibility & -0.101 & 0.371 & -0.040 & 0.730 & 0.002 & 0.988 & -0.066 & 0.558 \\
\hline Manageability & -0.329 & $0.009^{* *}$ & -0.298 & $0.021^{*}$ & -0.317 & $0.018^{*}$ & -0.350 & $0.006^{* *}$ \\
\hline Meaningfulness & -0.025 & 0.804 & -0.065 & 0.524 & 0.025 & 0.812 & -0.032 & 0.750 \\
\hline
\end{tabular}

$\beta$, standardized regression coefficient; $t$, value of test statistic; $p$, statistical significance, ${ }^{* *} p<0.01,{ }^{*} p<0.05$

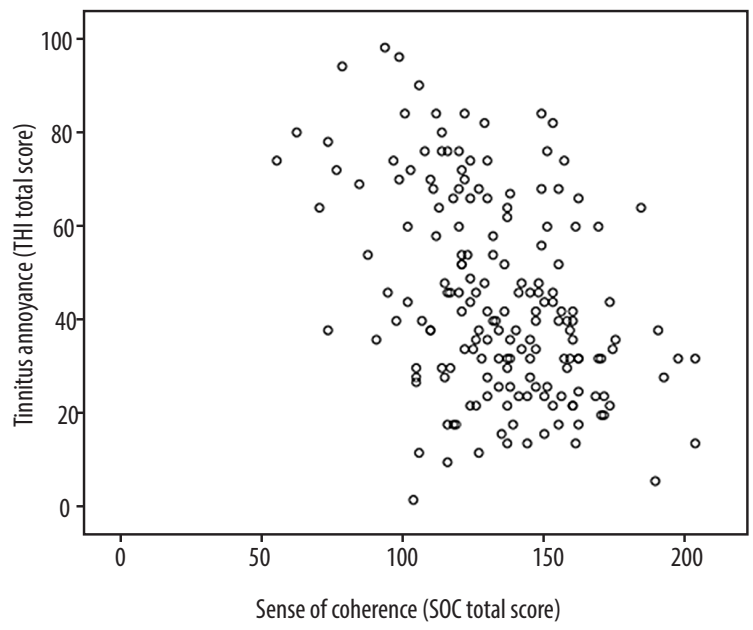

Figure 1. Relationship between tinnitus annoyance and sense of coherence

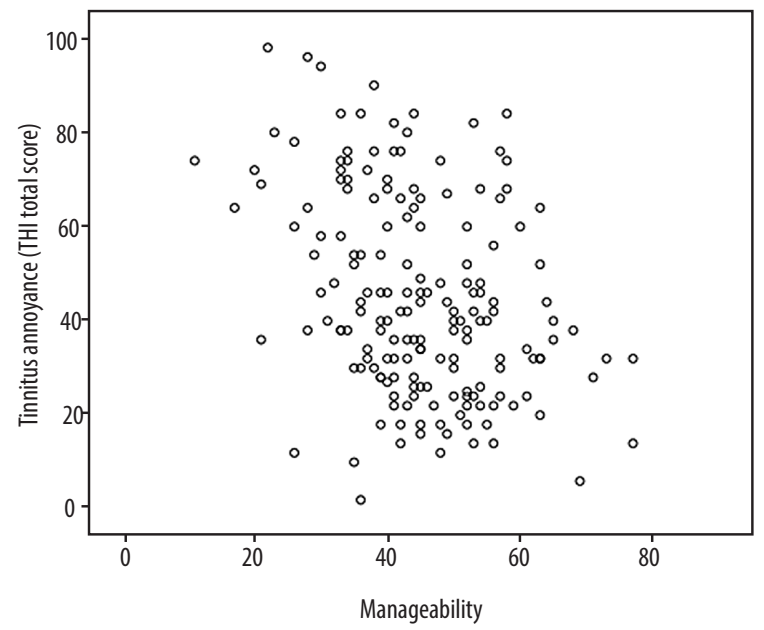

Figure 2. Relationship between tinnitus annoyance and manageability 
According to the authors of this study, mindfulness may promote a sense of manageability of the world by fostering more adaptive responses to stress. Mindfulness practice could also enhance SOC because moment-to-moment awareness may facilitate openness and making sense of experiences.

Other studies show the therapeutic effect of MindfulnessBased Interventions (MBI) in reducing distress associated with tinnitus [37]. Therefore, the sense of coherence is worth considering in future studies as a factor determining the effectiveness of this type of therapy in reducing the perceived annoyance of tinnitus. Research by Hourzad et al. examined the impact of the empowering self-management model on the sense of coherence of elderly people with chronic diseases. The concept of empowerment aims to encourage people to develop self-management with an emphasis on individual autonomy. Empowerment can be defined as the process by which people gain control over their lives (including disease) through being aware of the changes taking place, the ability to identify resources and use them adequately, and the feeling of being able to influence the situation. These studies have shown that the described intervention model can be used to strengthen the sense of coherence, especially the sense of manageability, in patients [38].

People with a strong sense of coherence experience less annoyance of tinnitus, and the research shows an increase in their sense of coherence after psychological therapies, which is inconsistent with Antonovsky's assumptions. In the case of tinnitus patients it is worthwhile undertaking psychological interventions aimed at strengthening this meta-resource, applying mindfulness therapies and the empowering self-management model.

In light of the presented positive relationship between the sense of coherence (a meta-resource) and the quality of life of people with tinnitus, it seems reasonable to broaden the research interest within the personal resources area. Further research could provide benefits in the search for new strategies to strengthen available resources for people with chronic conditions, as well as in identifying new ones. It is also worth incorporating the SOC concept in the pro-health efforts of specialists supporting people with chronic ailments.

\section{Conclusions}

- In people with a strong sense of coherence, and especially one of its components, the sense of manageability, one can expect a lower level of tinnitus annoyance.

- Psychological interventions (counselling, psychoeducation, psychotherapy) aimed at developing a sense of coherence may reduce the annoyance of tinnitus.

- Searches for other personal resources affecting tinnitus annoyance should be continued.

\section{References}

1. Kirenko J, Byra S. Personal Resources in Psychosomatic Diseases. Lublin: Wydawnictwo Uniwersytetu Marii Curie-Skłodowskiej; 2008; 75-107.

2. Antonovsky A. Unraveling the Mystery of Health. How people manage stress and stay well. Warsaw: Wydawnictwo Instytutu Psychiatrii i Neurologii; 2005.

3. Pruszewicz A. Clinical Audiology: Outline. Poznań: Wydawnictwo Akademii Medycznej im. Karola Marcinkowskiego; 2003.

4. Henry JL, Wilson PH. Coping with tinnitus: two studies of psychological and audiological characterstics of patients with high and low tinnitus-related distress. Int Tinnitus J, 1995; 1: 85-92.

5. Sarnicka I, Fludra M, Latkowska E, Borawska B, Karpiesz L, Bartnik G, Skarżyński H. Charakterystyka psychologiczna pacjentów z szumami usznymi na podstawie inwentarza osobowości oraz wybranych narzędzi pomiaru w psychologii zdrowia. In: Janowski K, Cudo A, editors. Człowiek Chory: Aspekty Biopsychospołeczne. Lublin: Best Print; 2009, 115-24.

6. Simões J, Schlee W, Schecklmann M. et al. Big five personality traits are associated with tinnitus improvement over time. Sci Rep, 2019; 9: 18234.

7. Andersson G, Vretblad P. Anxiety sensitivity in patients with chronic tinnitus. Scand J Behaviour Ther, 2000; 29(2): 57-64.

8. Hu J, Xu J, Streelman M, Xu H, Guthrie O. The correlation of the Tinnitus Handicap Inventory with depression and anxiety in veterans with tinnitus. Int J Otolaryngol, 2015; 2015:689375.

9. Yuri L, Taehwa K, Kieun L, Seungik J, Sungmin J, In-Ki J. The pathophysiology of tinnitus: involvement of the somatosensory, brain, and limbic systems. Audiol Speech Res, 2020; 16(1): 11-18.

10. Andersson G, McKenna L. The role of cognition in tinnitus. Acta Otolaryngol (Stockh.) 2006; suppl. 126: 39-43.
11. Tegg-Quinn S, Bennett RJ, Eikelboom RH, Baguley DM. The impact of tinnitus upon cognition in adults: a systematic review. Int J Audiol, 2016; 55(10): 533-40.

12. Kotyło P, Macheta K, Śliwińska-Kowalska M. Tinnitus annoyance and general health condition in patients with tinnitus before and after short-term tinnitus retraining therapy. Otolaryngol Pol, 2009; 8(1): 23-7.

13. Salazar JW, Meisel K, Smith ER, Quiggle A, McCoy DB, Amans MR. Depression in patients with tinnitus: a systematic review. Otolaryngol Head Neck Surg, 2019; 161(1), 28-35.

14. Pinto PC, Marcelos CM, Mezzasalma MA, Osterne FJ, de Melo Tavares de Lima MA, Nardi AE. Tinnitus and its association with psychiatric disorders: systematic review. J Laryngol Otol, 2014; 128(8): 660-4.

15. Koning HM. Sleep disturbances associated with tinnitus: reduce the maximal intensity of tinnitus. Int Tinnitus J, 2019; 23(1): 64-8.

16. Crönlein T, Langguth B, Pregler M, Kreuzer PM, Wetter TC, Schecklmann M. Insomnia in patients with chronic tinnitus: cognitive and emotional distress as moderator variables. J Psychosom Res, 2016; 83: 65-8.

17. Mazurek B. Tinnitus: new challenge and therapeutic approaches. HNO, 2018; 66(2): 47-8.

18. Sęk H. Introduction to Clinical Psychology. Warsaw: Wydawnictwo Naukowe Scholar; 2001.

19. Kulik L, Kronfeld M. Adjustment to breast cancer: the contribution of resources and causal attributions regarding the illness. Social Work in Health Care, 2005; 41(2), 37-57.

20. Pusswald G, Fleck M, Lehrner J, Haubenberger D, Weber G, Auff E. The "Sense of Coherence" and the coping capacity of patients with Parkinson disease. Int Psychogeriatr, 2012 Dec; 24(12): 1972-9.

21. Nahlén C, Saboonchi F. Coping, sense of coherence and the dimensions of affect in patients with chronic heart failure. Euro J Cardiovascular Nursing, 2010; 9(2), 118-25. 
22. Müller J, Hess J, Hager A. Sense of coherence, rather than exercise capacity, is the stronger predictor to obtain health-related quality of life in adults with congenital heart disease. Eur J Prev Cardiol, 2013; 21: 949-55.

23. Włodarczyk D, Wrześniewski K. Stress appraisal in terms of challenge in MI patients: an attempt in synthesis based on empirical data. Przegląd Psychologiczny, 2005; 48, 339-59.

24. Seydel C, Haupt H, Olze H, Szczepek AJ, Mazurek B. Gender and chronic tinnitus: differences in tinnitus-related distress depend on age and duration of tinnitus. Ear Hear, 2013; 34(5): 661-72.

25. Koniarek J, Dudek B, Makowska Z. The Sense of Coherence Questionnaire. Adaptation of the A. Antonovsky's Sense of Coherence Questionnaire (SOC). Przegląd Psychologiczny, 1993; $36,491-502$

26. Newman CW, Jacobson GP, Spitzer JB. Development of the Tinnitus Handicap Inventory. Arch Otolayrngol Head Neck Surg, 1996; 122: 143-8.

27. Skarżyński PH, Raj-Koziak D, Rajchel J, Piłka A, Włodarczyk A, Skarżyński H. Adaptation of the Tinnitus Handicap Inventory into Polish and its testing on clinical population of tinnitus sufferers. Int J Audiol, 2017; 24: 1-5.

28. Fludra M, Kobosko J, Gos E, Karendys-Łuszcz K, Skarżyński H. Role of personal resources from the perspective of experiencing tinnitus annoyance in adults. Eur Arch Otorhinolaryngol, 2020; 277, 1617-23.

29. Pasikowski T. Sense of Coherence Questionnaire for adults (SOC-29). In: Sęk H, Pasikowski T. ed. Health - Stress - Resources: The importance of a sense of coherence for health. Poznań: Wydaw. Fundacji Humaniora; 2001,71-85.
30. Eriksson M, Lindström B. Validity of Antonovsky's sense of coherence scale: a systematic review. J Epidemiol Community Health, 2005; 59(6): 460-6.

31. Eriksson M, Lindström B. Antonovsky's sense of coherence scale and the relation with health: a systematic review. J Epidemiology Community Health, 2006; 60: 376-81.

32. Kaczmarek $€$. The association between the sense of coherence and positive affect depend on the levels of stress. In: Sęk H, Pasikowski T. ed. Health Psychology: Theory, methodology, empirics. Poznań: Bogucki Wydawnictwo Naukowe; 2006.

33. Mroziak B. Sense of coherence (SOC) of alcohol addicts: changes after psychotherapy. In: Sęk H, Pasikowski T. ed. Health - Stress - Resources: The importance of a sense of coherence for health. Poznań: Wydaw. Fundacji Humaniora; 2001, 165-76.

34. Lundqvist T. Specific thought patterns in chronic cannabis smokers observed during treatment. Life Sci, 1995; 56(23-24): 2141-4.

35. Szymona, K. Changes of sense of coherence (SOC) after psychotherapy in neurotic patients. Psychiatria Polska, 2005; 39(4), 659-68.

36. Weissbecker I, Salmon P, Studts JL et al. Mindfulness-based stress reduction and sense of coherence among women with fibromyalgia. J Clin Psychol Med Settings, 2002; 9: 297-307.

37. Rademaker MM, Stegeman I, Ho-Kang-You KE, Stokroos RJ, Smit AL. The effect of mindfulness-based interventions on tinnitus distress: a systematic review. Front Neurol, 2019; 10: 1135.

38. Hourzad A, Pouladi S, Ostovar A, Ravanipour M. The effects of an empowering self-management model on self-efficacy and sense of coherence among retired elderly with chronic diseases: a randomized controlled trial. Clin Interv Aging, 2018; 13: 2215-24. 